\title{
Options for Using Low-quality Water for Vegetable Crops
}

\author{
Michael C. Shannon ${ }^{\mathbf{1}}$ and Catherine M. Grieve \\ U.S. Department of Agriculture, Agricultural Research Service, George E. Brown Jr., Salinity Laboratory, 450 \\ West Big Springs Road, Riverside, CA 92507-4617
}

At least two factors have led to increased interest in using lowquality, high-salinity water to grow crops. The first is the lack of drainage outlets in many agricultural areas of the world. In order to avoid lowering water quality for downstream users, regulations have evolved that mandate on-farm or regional strategies for reuse and/or disposal of saline drainage water. A second factor is that competition between agricultural and urban users for high-quality water has increased as the population has increased. Thus, agricultural users must rely more on low-quality water resources. Traditionally, growers have shifted from salt-sensitive crops to more tolerant species in order to avoid yield losses associated with high salinity. Usually this involves changing from crops of higher cash value to crops of lower value. Vegetable crops are generally less salt-tolerant and have higher cash value than most field and grain crops. Germplasm and management practices need to be improved to provide the grower with more economical and environmentally acceptable options for drainage water reuse. Some investigators have suggested that low-quality and high-quality waters can be used in successive applications during crop rotations or even within a rotation, if applied during growth stages that are more salt-tolerant or salt-sensitive, respectively. The addition of saline water during fruiting of melon (Cucumis melo L.) and tomato (Lycopersicon esculentum Mill.) has even been found to enhance sugar and soluble solid contents and to improve flavor and market price. Although much research is needed to quantitatively define salttolerant and salt-sensitive growth stages for vegetables, the potential high cash value of vegetable crops would go far in offsetting the costs

Received for publication 15 Sept. 1999. Accepted for publication 18 Oct. 1999. The cost of publishing this paper was defrayed in part by the payment of page charges. Under postal regulations, this paper therefore must be hereby marked advertisement solely to indicate this fact. Experimental portions of the research reported herein were funded by the California Dept. of Water Resources (DWR B-59922), Project Manager, Dr. Fawzi Karajeh.

'E-mail of corresponding author: mshannon@ussl.ars.usda.gov of drainage and water delivery systems necessary to implement water reuse practices. Vegetable crops that may be grown using the cyclic water-use strategies may include both traditional and potentially new species.

\section{SALINITY PROBLEMS}

In irrigated agriculture, salinity becomes a problem in two major ways. First, salt is imported with the irrigation water. Second, during the normal dissolution processes that occur in the soil, salt concentration increases, and changes in composition occur. As evaporation proceeds and water is transpired by plants, salts are concentrated in soils, often with devastating effects on both soils and crops. The total amount of salt imported through irrigation is often not fully comprehended. If Colorado River water at Parker Dam, Ariz., is taken as an example, the salinity may be in the range of $1 \mathrm{dS} \cdot \mathrm{m}^{-1}$, or $\approx 640 \mathrm{mg} \cdot \mathrm{L}^{-1}$ salt. To irrigate a crop like navel orange [Citrus sinensis (L.) Osbeck], annual consumptive water use is $\approx 1 \mathrm{~m}$, or $10,000 \mathrm{~m}^{3} / \mathrm{ha}$ of water containing $6400 \mathrm{~kg}$ of salt (ca. 2900 pounds of salt per acre). This does not take into account the import of water needed for leaching or the dissolution of salts that occur in the soil, or may be added as fertilizers. Even if water of high quality is used, annual salt imports in irrigated double-cropping systems can easily exceed $7500 \mathrm{~kg} \cdot \mathrm{ha}^{-1}$.

The build-up of salts in the root zone results in loss of yield and, possibly, the breakdown of soil structure. The local solution to the problem is to leach the salt from the root zone, a process that requires adequate drainage and the import of even more water to meet the leaching requirement (Rhoades, 1974). During the evolution of crop lands in the western United States, and in other countries as well, the expansion of agriculture began with the construction of conveyances to import water. The eventual decline of productivity due to increases in salinity finally led to the installation of drainage systems. This process, while probably making the most sense economically, is analogous to building a house, moving in and living there for a time, 
and then deciding to install the drains to the sinks and toilets. The socio-political pressures that perpetuate the repetition of the scenario described go well beyond the scope of this paper and have been the subject of previous commentary and controversy (van Schilfgaarde, 1994). On a larger scale, even when and if drainage is eventually provided, downstream users will suffer from the effects of leached salts. Salt that is returned to riparian systems that eventually drain to the ocean increases the salinity downstream. In Adelaide, Australia, water from the Murray-Darling watershed, after use and reuse along its course, arrives in Adelaide at salt concentrations exceeding those of sea water (Ghassemi et al., 1995). Rhoades and Dinar (1991) provided conceptual and empirical evidence to show how water use on hypothetical farming systems along a river can diminish water quality for downstream users. The model that they developed tested the advantages and disadvantages of three options for water use. The first option used river water to irrigate four crops on identical farms located along the river course; drainage simply was returned to the river. In a second option, drainage from each of the four farms was collected for three salt-sensitive crops and blended to provide irrigation water for a salttolerant cotton (Gossypium hirsutum L.) crop before being returned to the river. The third option was similar to the second, except that drainage from the cotton crop was not returned to the river, but put into an evaporation pond. This study showed that returning drainage water to conveyance systems significantly reduced yields and profitability for downstream users (Table 1).

In the Imperial and Coachella Valleys of California, imported water from the Colorado River that is used for agriculture does not return to the conveyance system, but eventually drains to the Salton Sea. During the last four decades, the salinity of this body of water has increased to concentrations in excess of sea water, and salinity and selenium have become threats to recreational use of the sea and to its associated wildlife habitats. In another example, water from agricultural operations in the productive Central Valley of California was collected by the San Luis Drain. Part of this drainage system became a drainage reservoir (Kesterson) when conservationists blocked completion of drain construction because of concerns about impacts of the drainage on the habitat of the Sacramento Delta. In 1981, high selenium levels found in the food chain at the Kesterson Wildlife Refuge were discovered to be the cause of deformities in and deaths of many bird species. This finding led to the closure of Kesterson, the passage of laws that limit drainage into the reservoir, and the eventual development of a program to take selected types of agricultural land out of production (Interagency Land Retirement Team, 1996).

Because of the diverse detrimental effects of drainage water, whether returned to conveyance systems or stored in reservoirs, proposals for on-farm reuse of water have been seriously considered. One strategy, termed blending, proposes that high quality water be added to drainage water to decrease its salinity below the level that would negatively impact crop yield. Another concept of drainagewater use would be the cyclic use of nonsaline irrigation water and saline drainage water in successive irrigations. Such a strategy might involve using water of high quality on crops that are salt-sensitive and more saline water on tolerant crops, or it might involve providing

Table 1. Comparison of simulation results from a model for three different strategies of drainage management along a riparian waterway. ${ }^{2}$

\begin{tabular}{lcccccc}
\hline \hline & $\begin{array}{c}\text { Water } \\
\text { used }\end{array}$ & $\begin{array}{c}\text { Drainage } \\
\text { produced }\end{array}$ & \multicolumn{2}{c}{$\begin{array}{c}\text { Accumulative yield loss } \\
\text { for all crops (\%) }\end{array}$} & \multirow{2}{*}{$\begin{array}{c}\text { Downstream } \\
\text { river water }\end{array}$} \\
\cline { 4 - 6 } Strategy & vol $^{\mathrm{y}}$ & vol $^{\mathrm{y}}$ & Farms 1 \& 2 & Farm 3 & Farm 4 & quality $\left(\mathrm{EC}_{\mathrm{r}}\right.$ ) \\
\hline 1 & 496 & 77.9 & 0 & 2 & 20 & 3.0 \\
2 & 428 & 10.2 & 0 & 4 & 45 & 3.0 \\
3 & 428 & 0 & 0 & 0 & 0 & 0.5 \\
\hline
\end{tabular}

${ }^{2}$ The model assumes that in each strategy four identical farms located along a river use identical amounts of water to irrigate identical acreages of beans (Phaseolus vulgaris L.), alfalfa (Medicago sativa L.), wheat, and cotton. In Strategy 1 , no water is reused and all drainage is returned to the river; in Strategy 2 , drainage from the first three crops is collected to irrigate cotton, and resultant drainage is returned to the river. Strategy 3 is similar to Strategy 2, except that drainage from the cotton is not returned to the river (assumes on-farm disposal) ${ }^{y}$ Unitless parameters. They apply to any volume measured in the model (Rhoades and Dinar, 1991). saline or nonsaline water to the same crop during growth stages that differ in salt tolerance.

\section{SALT TOLERANCE OF FRUITS AND VEGETABLES}

The incorporation of more salt-tolerant crops into the rotation cycle has been one method that growers have used to manage soil and water salinity. Unfortunately, fruits and vegetables are among the least salttolerant crops. Generally, salinity reduces yield. This reduction may be accompanied by a complete lack of visual symptoms and may go undetected by the grower. A threshold salinity level usually exists below which yield is unaffected and above which yield declines at a linear rate (Fig. 1). These parameters are referred to as the threshold $(t)$ and slope $(s)$, respectively, and have been described in detail elsewhere (Maas, 1990; Shannon, 1997). The salt tolerance of a large number of crops, based on their respective $s$ and $t$ values, has been described as a result of years of research at the Salinity Laboratory and other locations (Maas, 1990; Maas and Hoffman, 1977). This work shows that most vegetables fall within the sensitive and moderately sensitive categories, and that many fruits are quite sensitive as well (Fig. 2). The rigorous research and interpretation that led to the definition of these salt-tolerance parameters were based on studies conducted under uniform stress applied soon after plant establishment and maintained throughout the growth cycle. Although useful, the data do not permit interpretation of the effects of using nonsaline and saline water in a cyclic strategy. Many studies have demonstrated that plant salt tolerance can vary with growth stage (see Maas and Poss, 1989), leading to optimism for the potential of cyclic reuse within a cropping season. Unfortunately, this aspect adds yet another complication to the development of predictive tools for the use of saline water in agriculture.

\section{CYCLIC REUSE}

Several studies with field crops have tested the feasibility of using nonsaline water to irrigate moderately salt-sensitive crops or to establish more tolerant crops during their sensitive growth stages, and then using more saline waters after the plants have reached more salttolerant stages of growth (Rhoades, 1989). These studies suggest that irrigation waters previously classified as too saline for use without an expected reduction in yield can often be used without discernible yield loss. Saline water applied during specific growth stages may even improve the quality of many fruits and vegetables by increasing sugar and soluble solids contents (Pasternak et al., 1986). Processing tomatoes have been grown with saline and nonsaline water, using the cyclic water strategy, without measurable loss of yield and with associated increases in fruit quality because of higher soluble solids content (Grattan et al., 1987). Applying saline water to safflower (Carthamus tinctorius L.) increased the proportion of favorable fatty acids (Irving et al., 1988). Shannon and Francois (1978) found that water of higher

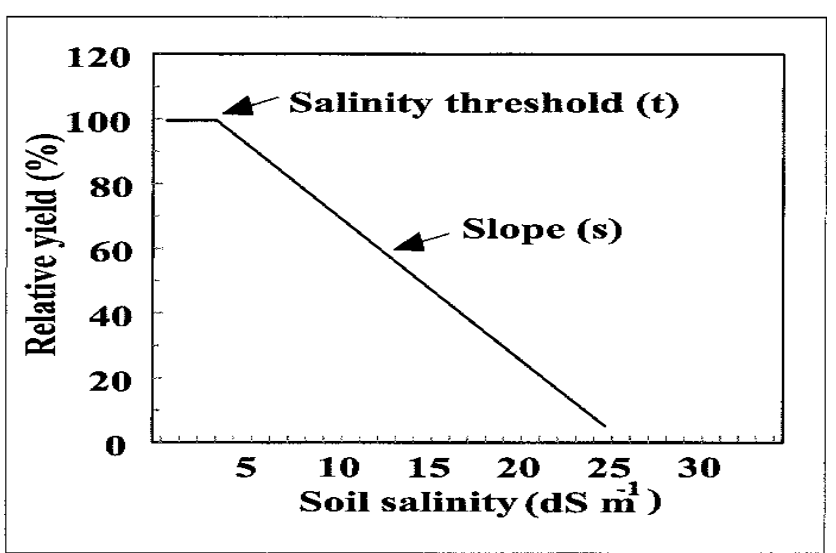

Fig. 1. The piece-wise, linear-response salinity function, where $t$ is the salinity of the threshold and $\mathrm{s}$ is the percentage yield decrease per unit salinity increase. 


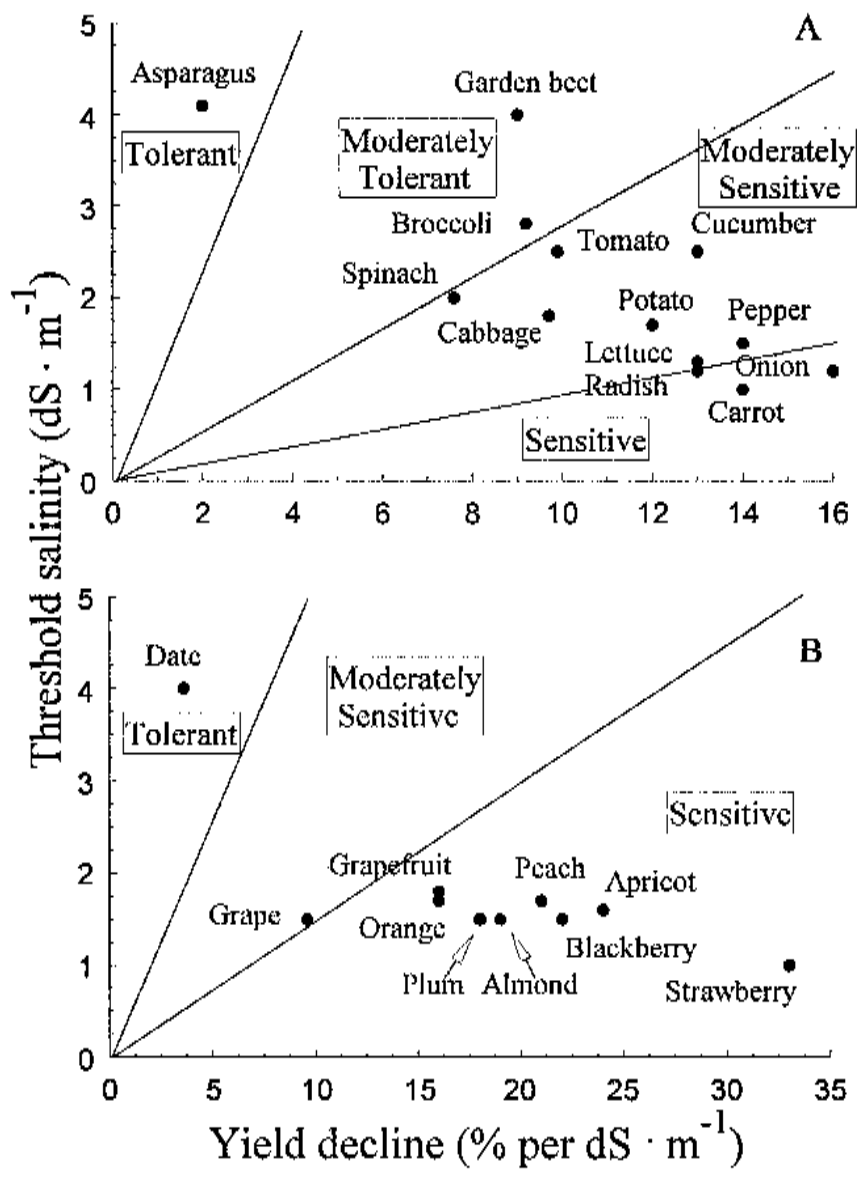

Fig. 2. Salinity classifications based on threshold and slope values for some vegetable (A) and fruit (B) crops (after Shalhevet, 1994). Crops include almond [Prunus dulcis (Mill.)], apricot (Prunus armenica L.), blackberry (Rubus fruticosa Auct.), date (Phoenix dactylifera L.), grape, grapefruit (Citrus paradisi Macf.), orange, peach [Prunus persica (L.) Batsch)], plum (Prunus domestica L.), strawberry (Fragaria $\times$ ananassa Duch.), carrot (Daucus carota L.), onion (Allium cepa L.), radish (Raphanus sativus L.), lettuce (Lactuca sativa L.), pepper (Capsicum frutescens L.), broccoli (Brassica oleracea, Botrytis group), cabbage (B. oleracea, Capitata group), spinach, cucumber (Cucumis sativus $\mathrm{L}$.), tomato, potato (Solanum tuberosum L.), garden beet (Beta vulgaris L.), and asparagus.

salinity increased the sugar content of cantaloupe (Cucumis melo L.) as much as $2 \%$. Soluble solids of asparagus (Asparagus officinalis L.) spears also increased from 95 to $108 \mathrm{mg} \cdot \mathrm{g}^{-1}$ fresh weight when soil salinity approached $21 \mathrm{dS} \cdot \mathrm{m}^{-1}$ (Francois, 1987).

Salinity may alter both growth and development. Saline water applied after tiller formation in wheat (Triticum aestivum L.) reduced future spike size and yield, and decreased time to maturity. However, if saline water was applied during the early stages of tillering and then flushed from the root zone, no loss of yield resulted (Francois et al., 1994). An extrapolation of these concepts leads to the premise that growing high-value horticultural crops using saline drainage water may be possible in conjunction with cyclic water-use strategies, as a means of offsetting some of the higher input costs associated with the water management requirements of such systems. Horticultural crops may prove quite suitable for such use for well-designed and wellmanaged irrigation systems, because the value of the marketable product is higher than that of field crops and may be more dependent on quality than on biomass yield. The effects of salinity on the value of many horticultural species, such as herbs, spices, oils and medicinal plants, also have not been investigated. In addition, little research has been conducted to determine the potential of offsetting yield losses due to salinity through the use of improved management techniques, such as cyclic application of saline water, increasing planting density, improving quality characteristics, and hastening maturity.

\section{EXPERIMENTAL STUDIES}

A series of experiments were conducted at the Salinity Laboratory during 1996 and 1997 to determine the potential for growing leafy vegetables using relatively saline irrigation waters. Briefly, different concentrations of saline drainage water were applied to several leafy vegetable species at different stages of growth. Leafy vegetables were selected for this test based on the concept that plant size was less important than quality, and that increases in planting density could compensate, at least partially, for the expected reduction in size. California is a leading, year-round producer of leafy oriental vegetables, and, although information on the salt tolerance of these crops is generally lacking, some vegetables might fill niches in the drainage water reuse system when only moderate tolerance is required. Salinities were imposed at different growth stages to determine plant response. Previous work had shown that euhalophytes have much wider ranges in ion accumulation and tolerance characteristics than most crop species (Hoffman and Shannon, 1986). Several vegetable species, including Swiss chard [Beta vulgaris L., var. flavescens (Lam.) Lam.], spinach (Spinacia oleracea L.), purslane (Portulaca oleracea L.), New Zealand spinach [Tetragonia tetragonioides (Pall.) O. Kuntze], orach (Atriplex hortensis L.), and certain types of mustard greens [Brassica juncea (L.) Czerniak], belong to families whose members grow vigorously in highly saline environments. Thus, these species could have a place in cropping systems for drainage water reuse.

In experiments conducted in sand tanks outdoors at Riverside, Calif., seeds of nine species of leafy vegetables were planted on $30 \mathrm{Jan}$. 1997. Saline irrigation waters were synthesized based on observed data for drain water collected at several locations in the San Joaquin Valley. Based on the model of Suarez and Simunek (1997), salinity was increased to simulate typical soil-water interactions, including absorption, desorption, dissolution, and precipitation (Table 2). The solutions also contained sufficient nitrate, phosphate and essential micro nutrients. "Early" salinization was initiated when the first pair of true leaves was fully expanded on more than half of the plants (17 Feb.). "Late" salinization was imposed based on cumulative thermal time. Final electrical conductivities were $3,7,11,15,19$, and 23 $\mathrm{dS} \cdot \mathrm{m}^{-1}$. The experimental design was a randomized block with six salinity treatments, two salinization dates ("early" and "late"), and two replications. Species studied included two chenopods (spinach cv. Space and Swiss chard cv. Ruby Red Chard); five brassicas \{mustard greens cvs. Vitamin Green (Brassica rapa L., Narinosa group) and Red Giant [B. juncea (L.) Czernj. \& Coss.]; pac choi (B. rapa L., Chinensis group); kale cv. Winterbor (B. oleracea L., Acephala group); tatsoi (B. rapa L., Narinosa group \}; and two composites [curly endive (Cichorium endivia L., Wallone type), and radicchio ( $C$. intybus L.) cv. Red Preco No. 1]. A second trial, employing identical salinity levels and solution compositions, included orach (Atriplex hortensis L.) and New Zealand spinach [Tetragonia tetragonioides (Pall.) O. Kuntze]. Both of these species may be used as late-summer substitutes for spinach.

Routine measurements were taken to determine the combined effects of salinity and planting date on number and size of leaves, rate of leaf appearance, leaf area, and photosynthetic rate. At final harvest, fresh and dry weights were determined and shoot material was sampled for ion content. Only partial results will be presented in this report.

Table 2. Concentrations of ions (meq. $\left.\mathrm{L}^{-1}\right)$ in the treatment irrigation waters. ${ }^{2}$

\begin{tabular}{lrrrrrr}
\hline \hline $\begin{array}{l}\text { Solution electrical } \\
\text { conductivity }\left(\mathrm{dS} \cdot \mathrm{m}^{-1}\right)\end{array}$ & \multicolumn{6}{c}{ Ion concn (meq. $\left.\mathrm{L}^{-1}\right)$} \\
\cline { 2 - 7 } & $\mathrm{Ca}^{2+}$ & $\mathrm{Mg}^{2+}$ & $\mathrm{Na}^{+}$ & $\mathrm{K}^{+}$ & $\mathrm{SO}_{4}{ }^{2-}$ & $\mathrm{Cl}^{-}$ \\
\hline 3 & 7.0 & 4.9 & 21.5 & 3.0 & 21.8 & 10.6 \\
7 & 14.6 & 11.5 & 50.9 & 3.0 & 51.7 & 24.7 \\
11 & 20.3 & 19.6 & 87.0 & 3.0 & 84.0 & 42.2 \\
15 & 26.0 & 27.8 & 123.0 & 3.0 & 116.0 & 59.6 \\
19 & 26.9 & 37.9 & 168.0 & 3.0 & 150.0 & 81.3 \\
23 & 27.3 & 48.7 & 216.0 & 3.0 & 187.0 & 98.5 \\
\hline
\end{tabular}

${ }^{2}$ Target values were determined on observed data for drainage water collected at several locations in the San Joaquin Valley and model simulations (Suarez and Simunek, 1997). 


\section{RESULTS AND DISCUSSION}

Although salt tolerance differed among species, yields of all the vegetables were improved when application of high salinity drainage water was delayed until later in the growing season. The effects varied with the species. For example, late salinization of spinach and kale increased the threshold tolerance, and yet relative yield reduction (the percentage of yield decline relative to the control) was about the same. In contrast, there were no significant differences in the threshold salinity or yield decrease due to the onset of salinization in pac choi except at the highest salinity level (Fig. 3). Other than the decreases in size, no adverse visual effects were noted that would reduce marketability. In most instances the vegetables grown under high salinity were also a darker green, a characteristic that may improve marketability. Irrigation with saline waters high in sulfate also seemed to enhance the flavor of the leafy cruciferous vegetables.

Fresh weight of kale was not significantly reduced by earlier salination for salinities $<18 \mathrm{dS} \cdot \mathrm{m}^{-1}$. In outdoor plots, yields of several vegetables were higher at $6 \mathrm{dS} \cdot \mathrm{m}^{-1}$ than at $3 \mathrm{dS} \cdot \mathrm{m}^{-1}$. Overall, orach appeared to have greater salt tolerance than the other vegetables planted in outdoor plots, especially when salinity was imposed $33 \mathrm{~d}$ after seeding. The maximum vegetative yield (fresh weight) of orach was $<160 \mathrm{~g}$ per plant, whereas yields of pac choi and New Zealand spinach were $\approx 600 \mathrm{~g}$. Thus, the potential for water use may be higher for crops with higher yield potentials. Nevertheless, options may exist for increasing planting density of lower yielding, more salt-tolerant species in order to maximize water use on a land area basis.

Vegetable yields appeared to respond to a thermal time-weighted average salinity. Although salinity reduced overall size of many individual vegetables, proper management might allow higher population densities, which could offset some yield reduction; i.e., smaller plants, but more plants produced.
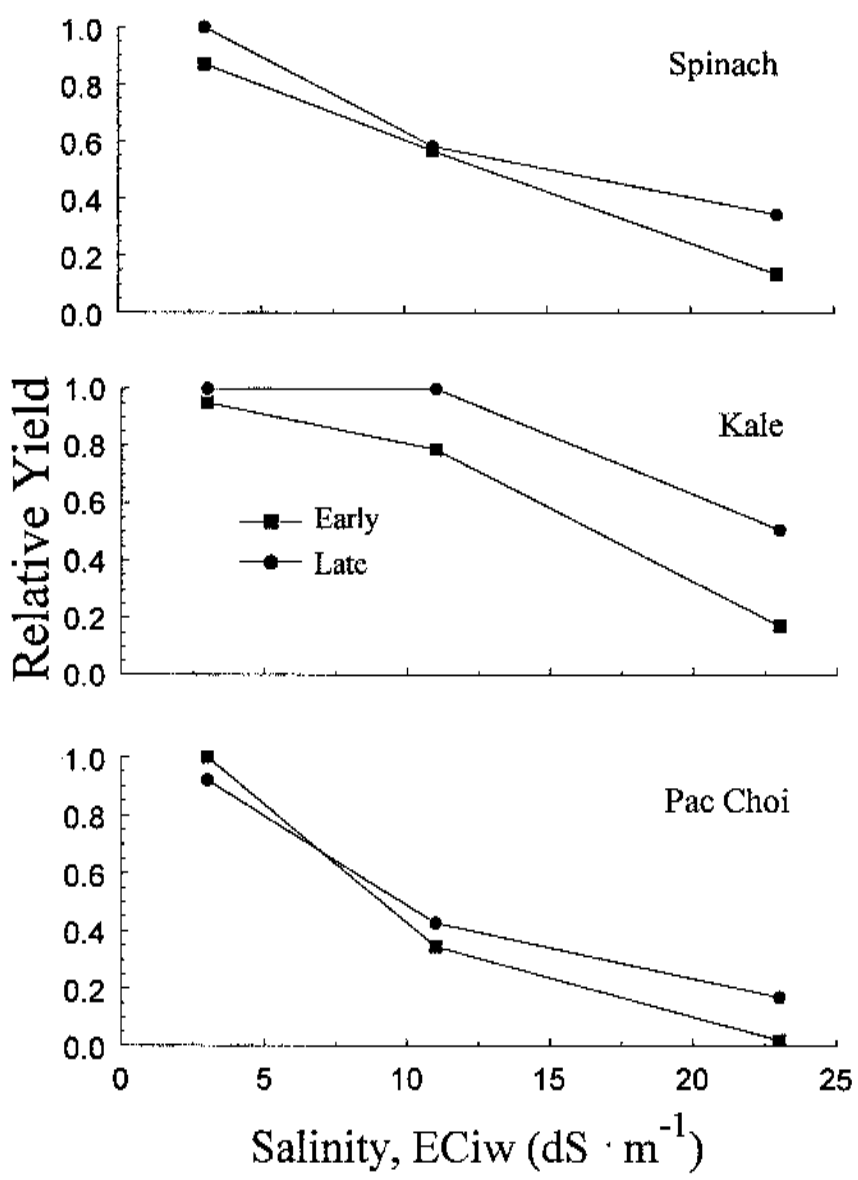

Fig. 3. Relative yields of spinach, kale and pac choi as a function of salinity level. Salt stress initiated at $19(\boldsymbol{\square}$, Early) or 40 (@, Late) days after planting.
Ion analyses of leaves indicated that salt accumulation was primarily a result of applied salinity, but ion ratios were species-specific, with fewer differences occurring as a result of the duration of salt exposure. For example, $\mathrm{Na}^{+}$concentrations in spinach leaves, calculated on the basis of plant water content, were lower than treatment concentrations in the root zones at all salinities (Fig. 4A). Kale also had low leaf $\mathrm{Na}^{+}$levels compared with orach and pac choi, which had 2to 3-fold higher concentrations, even at low salinity levels. Chloride concentrations in leaves were subsequently higher for pac choi than for the other species (Fig. 4B). Concentrations of $\mathrm{Ca}^{2+}$ and $\mathrm{SO}_{4}{ }^{2-}$ in the leaves of the chenopods, spinach and orach, were low under all salinity treatments. For the Brassica species kale and pac choi, however, lower leaf $\mathrm{Ca}^{2+}$ levels were found under saline than nonsaline conditions (Figs. 4 A and B), indicating a potential salinity-induced nutritional problem (Grattan and Grieve, 1994). Sodium-induced calcium deficiency can result in internal browning of artichoke (Cynara scolymus L.) buds (Francois et al., 1991) and contributes to a higher incidence of blossom-end rot in tomato (Ho et al., 1995). In saline soil solutions, chemical solubility and precipitation reactions can limit the amounts of available $\mathrm{Ca}^{2+}$ (Table 2) and lead to deficiency problems for species that have a high $\mathrm{Ca}^{2+}$ requirement or are inefficient in taking up this cation. Several genes that influence $\mathrm{Ca}^{2+}$ efficiency occur in tomato (Giordano et al., 1982). The ability of plants to accumulate or exclude nutrients and potentially toxic ions (bioremediation) is an important area of future research in technology for reuse of drainage water. In our studies, only minor changes in leaf ion concentrations occurred as a result of longer salinization time, suggesting that growth rate and ion uptake were in balance.

In conclusion, fitting horticultural crops into cyclic water reuse systems may be possible. The high cash value of horticultural crops is justification for consideration of such species in systems that already require high inputs of water and crop management. If salt tolerance

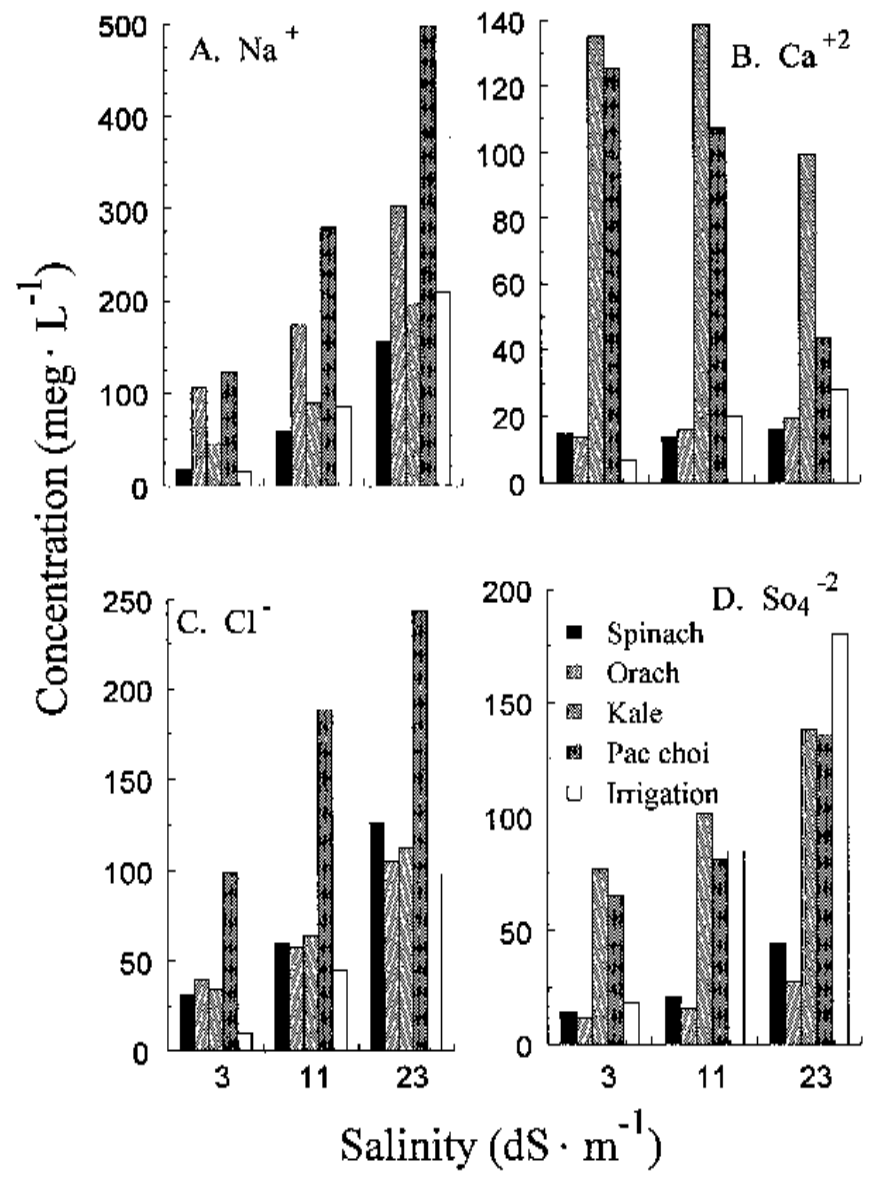

Fig. 4. Ion concentrations calculated on the basis of leaf water content of 63day-old spinach, orach, kale, and pac choi grown at three salinity concentrations ( $\mathbf{A}=$ sodium; $\mathbf{B}=$ calcium $; \mathbf{C}=$ chloride $; \mathbf{D}=$ sulfate $)$. 


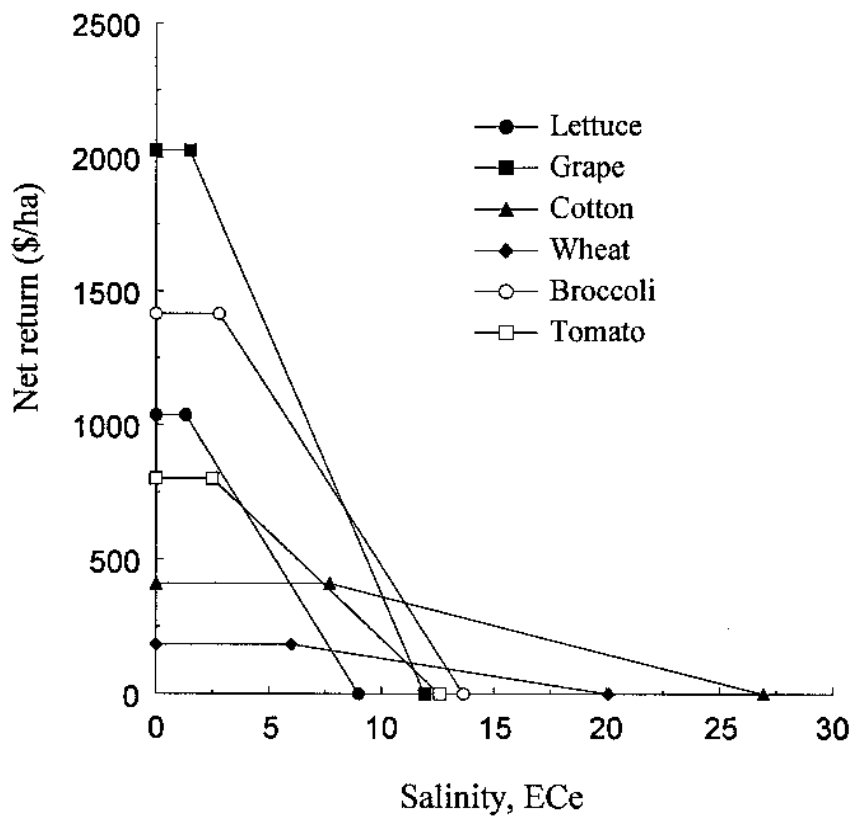

Fig. 5. An adaptation of the piece-wise, salt-response curve based upon potential value per hectare as influenced by salinity. Values for potential returns represent gross income based on actual average yields and commodity values (US \$) from the 1996 Agricultural Crop Reports of Imperial, Kern, King, Riverside, and Tulare counties in California. Figures used are for raisin grapes (Vitis sp.), processing tomato, and cotton (Gossypium hirsutum L.) lint.

parameters of $t$ and $s$ are plotted against gross returns per hectare instead of relative yield, the potential rewards of using high value horticultural crops for the reuse of saline drainage water are more easily recognized (Fig. 5). Reduced plant size due to salinity may be offset in part by closer plant spacing. In addition, the effects of salinity on the harvest index of crops such as herbs, spices, medicinals, cut flowers, and industrials is an area that needs much additional research. Finally, the problem still exists of what to do with the secondary or tertiary drainage water that will be generated from water reuse systems. Rhoades and Dinar (1991) have demonstrated the negative impacts of returning this drainage water to potential water delivery systems (Table 1). Several methods exist, including evaporation ponds and deep-aquifer injection, that can serve as temporary solutions. However, long-term, sustainable solutions are needed to deal with the 3 to 4 tonnes of salt per hectare per year that can be generated through the import of water for irrigation. Unless this problem is solved, future generations may look back on today's agriculture and find abandoned fields, ruined cities and pillars of salt.

\section{Literature Cited}

Francois, L.E. 1987. Salinity effects on asparagus yield and vegetative growth. J. Amer. Soc. Hort. Sci. 112:432-436.

Francois, L.E., T.J. Donovan, and E.V. Maas. 1991. Calcium deficiency of artichoke buds in relation to salinity. HortScience 26:549-553.

Francois, L.E., C.M. Grieve, E.V. Maas, and S.M. Lesch. 1994. Time of salt stress affects growth and yield components of irrigated wheat. Agron. J. 86:100-107.

Ghassemi, F., A.J. Jakeman, and H.A. Nix. 1995. Salinisation of land and water resources. Univ. New South Wales Press, Sydney, Australia.

Giordano, L. deB., W.H. Gableman, and G.C. Gerloff. 1982. Inheritance of efficiency of calcium utilization by tomatoes under low-calcium stress. J. Amer. Soc. Hort. Sci. 107:664-669.

Grattan, S.R. and C.M. Grieve. 1994. Mineral nutrient acquisition and response by plants grown in saline environments, p. 203-226. In: M. Pessarakli (ed.). Handbook of plant and crop stress. Marcel Dekker, New York.

Grattan, S.R., C. Shennan, D.M. May, J.P. Mitchell, and R.G. Burau. 1987. Use of drainage water for irrigation of melons and tomatoes. Calif. Agr. 41(9/10):2728.

Ho, L.C., P. Adams, X.Z. Li, H. Shen, J. Andrews, and Z.H. Xu. 1995. Responses of Ca-efficient and Ca-inefficient tomato cultivars to salinity in plant growth, calcium accumulation and blossom-end rot. J. Hort. Sci. 70:909-918.

Hoffman, G.J. and M.C. Shannon. 1986. Relating plant performance and soil salinity. Reclam. Reveg. Res. 5:211-225.

Interagency Land Retirement Team. 1996. Land retirement program interim guidelines. Central Valley Project Improvement Act Section 3408(h). U.S. Dept. Interior, Fresno, Calif

Irving, D.W., M.C. Shannon, V.A. Breda, and B.E. Mackey. 1988. Salinity effects on yield and oil quality of high-linoleate and high-oleate cultivars of safflower (Carthamus tinctorius L.). J. Agr. Food Chem. 36:37-42.

Maas, E.V. 1990. Crop salt tolerance, p. 262-304. In: K.K. Tanji (ed.). Agricultural salinity assessment and management. ACSE Manuals and Reports on Engineering Practice No. 71., Amer. Soc. Civil Eng., New York.

Maas, E.V. and G.J. Hoffman. 1977. Crop salt tolerance-Current assessment. J. Irr. Drain., Div. ASCE, 103(IR2):115-134

Maas, E.V. and J.A. Poss. 1989. Salt sensitivity of wheat at various growth stages. Irr. Sci. 10:29-40.

Pasternak, D.A., Y. DeMalach, and J. Borovic. 1986. Irrigation with brackish water under desert conditions. VII. Effect of time of application of brackish water on production of processing tomatoes (Lycopersicon esculentum Mill.). Agr. Water Mgt. 12:149-158.

Rhoades, J.D. 1974. Drainage for salinity control, p. 433-462. In: J. van Schilfgaarde (ed.). Drainage for agriculture. Amer. Soc. Agron., Monogr. No. 17. Madison, Wis.

Rhoades, J.D. 1989. Intercepting, isolating and reusing drainage waters for irrigation to conserve water and protect water quality. Agr. Water Mgt. 16:37-52

Rhoades, J.D. and A. Dinar. 1991. Reuse of agricultural drainage water to maximize the beneficial use of multiple water supplies for irrigation, p. 99-115. In: A Dinar and D. Ziberman (eds.). The economics and management of water and drainage in agriculture. Kluwer, Boston.

Shalhevet, J. 1994. Using water of marginal quality for crop production: Major issues. Agr. Water Mgt. 25:233-269.

Shannon, M.C. 1997. Adaptation of plants to salinity. Adv. Agron. 60:75-120.

Shannon, M.C. and L.E. Francois. 1978. Salt tolerance of three muskmelon cultivars. J. Amer. Soc. Hort. Sci. 103:127-130.

Suarez, D.L. and J. Simunek. 1997. UNSATCHEM: Unsaturated water and solute transport model with equilibrium and kinetic chemistry. Soil Sci. Soc. Amer. J. 61:1633-1646.

van Schilfgaarde, J. 1994. Irrigation-A blessing or a curse. Agr. Water Mgt. 25:203-219. 